\title{
PREVENTION OF MONEY LAUNDERING IN THE BANKING SECTOR
}

\section{Ljubomir Miljkovic}

Faculty of Business and Law, University "Union - Nikola Tesla", Belgrade, Serbia

\section{Dragana Trnavac}

Faculty of Business and Law, University "Union - Nikola Tesla“, Belgrade, Serbia

\section{Ratomir Antonovic Holding Company Fond "Inex Interexport" AD Belgrade, Belgrade, Serbia}

OMESTE

JEL Category: G21, K42

\begin{abstract}
One of the key issues in the organized crime world is the financing of criminal activities. Therefore, to successfully provide the necessary means for criminal actions, it uses various illegal methods and crimes. The money laundering attempts to hide the trace of money acquired through the act of a criminal offense in a way that it is inserted into legal cash flows. For this purpose, banks are often used in many ways - through deposits, money transfers abroad, and payment of counterfeit bills, credit transactions, and similar actions. Also, the so-called correspondent banking should be mentioned here, which effectively traces money in the co-operation of several banks. The central place of this work is the prevention of money laundering by the abuse of the banking sector. This is achieved through a strong control of the banking sector and operations by the central bank, then by drafting and adopting legislation and bylaws, which regulate mechanisms for reducing money laundering and financing terrorism and organized crime through financial institutions. The Central Bank is tasked with issuing recommendations for the improvement of the money-laundering system, cooperating with specialized bodies working on the prevention of money laundering, both at the national and international level, direct control over the taxpayers, and contacts with them. In the system of the Republic of Serbia, the National Bank of Serbia has the role of a supervisor in the banking system. In the case of detection of weaknesses in this system, the National Bank shall take appropriate steps in the form of correction of the minor system of moneylaundering prevention and take corrective measures, following the legal regulations.
\end{abstract}

Keywords: Money, laundering, crime, prevention, measures, banking sector.

\section{INTRODUCTION}

Address of the corresponding author:

Ljubomir Miljkovic

䒠=1jubomir.miljkovic@ppf.edu.rs
Money laundering is a criminal act that can be defined as concealing the origin of money coming from illegal sources, with the tendency to act as 
legal money. Money laundering is closely linked to corruption, smuggling, financial fraud, and organized crime, and as a criminal offense, it falls into the category of derivative offenses, as it usually follows after some other work through which the money is illegally acquired. The very concept of money laundering is related to the United States, in the 1930s when money launderers were illegally acquired from the sale of alcohol, which at that time was banned, reported as their legal profits from car wash and laundry. In this regard, the term money laundering has been adopted, which is today very widespread in all countries of the world and represents one profoundly serious problem.

Money laundering is particularly important for the functioning of criminal organizations, which mainly from illegal funds finance their criminal activities. It is a complex work because it includes a series of actions aimed at concealing the origin of money illegally obtained and presenting it as a legal one. Given the complexity of this operation itself, it is clear that persons from criminal structures have to devise various money laundering mechanisms, which could, in a more efficient way, achieve their ultimate goal. Also, the money laundering process has its own three phases. These are the investment phase, the concealment stage, and the integration phase. Of this, it is also the most complex for the perpetrators of this part, the most important second phase, because it practically means legalizing the controversial money. (Bejatovic \& Bejatovic, 2017, pp. 331-340)

The harmfulness of money laundering can be addressed in several aspects. Firstly, money laundering negatively affects the business of legal entities that directly violate business ratings and rules of free economic activity and competition. The tax burden is also borne by the tax sector, which is deprived of a significant amount of money, which avoids regular taxation. Money laundering seriously undermines the stability of the domestic currency exchange rate, and the stability of interest rates, money demand, and so on is jeopardized. (Boskovic, 2004, pp. 277-288)

In countries that are in the process of transition and development, the phenomenon of money laundering is much more prevalent. This is because these countries went through a very turbulent and non-transparent process of ownership transformation and that a significant amount of new capital entered those countries, for which it was often not possible to establish the origin with certainty. Money laundering in these countries results in unfair and unlawful privatization of the public sector, in which favored those who have come to the capital often illegally, which has denied investors who operate legally. Unfair competition and the creation of a certain suspicious layer of extremely rich individuals, who, apart from having a capital of dubious origin, have a very high political and social impact, contribute to the establishment of corruptive business conditions and unfair selection of market participants.

\section{AMOUNTS OF MONEY LAUNDERING IN BANKING SECTOR}

Money laundering in the banking sector is very widespread. Money laundering mechanisms in the banking sector are diverse, and the essence of this money laundering is the deposit of cash in cash or the purchase of payment instruments, the transfer of money abroad, and the subsequent integration of money into legal frameworks through repayment of loans, payment of simulated and falsified accounts. These three phases can be played at the same time, at the same time interval, and maybe time separated.

Money laundering can be done through correspondent accounts, when the banking services of a bank are provided through another bank, with the existence of a correspondent account on which the funds are located. By establishing global correspondent relationships, banks perform international transactions, both for themselves and their clients, even in those countries where they do not have their branches. Correspondent banking includes interbank deposit activities, international electronic system transfers, cash management, payments, and payments and transfers from foreign bank accounts. The space for abuses is created by avoiding direct contact between the bank and the client, but the services are performed without prior authentication. As a result, users of correspondent banking services are often "offshore" companies, there are no clearly defined anti-money laundering mechanisms and there is no possibility of 
controlling individual transactions that are part of large transactions.

Also, electronic money transfers are often like money laundering. It is about online banking, where the transaction is done via the Internet and using modern technological means. The bank does not have any insight into these transactions, and whether or not the account was accessed by its owner or another person. This allows persons dealing with criminal acts of money laundering to make illegal activities easier, and it is also more difficult to get into electronic money because it can be transferred to the whole world without any difficulty.

\section{PROCEEDS}

FROM ILLICIT ACTIVITY

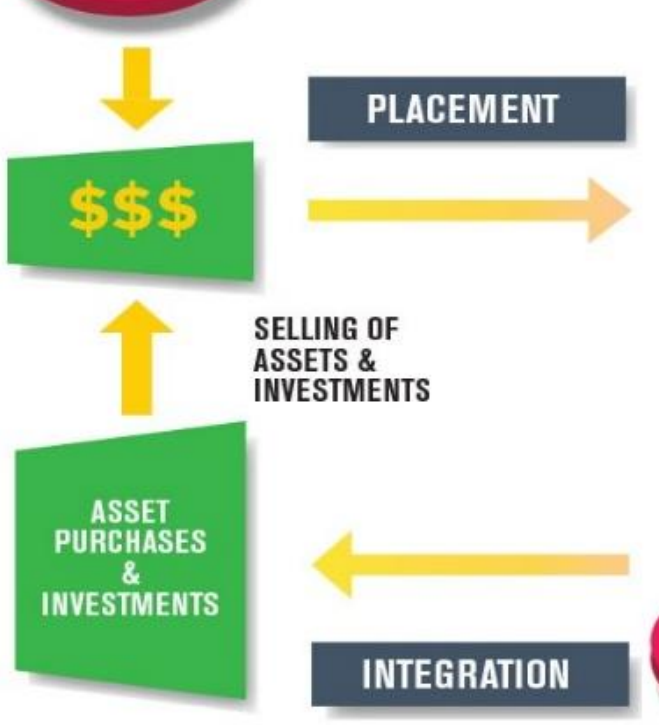

\section{Money Laundering Scheme}

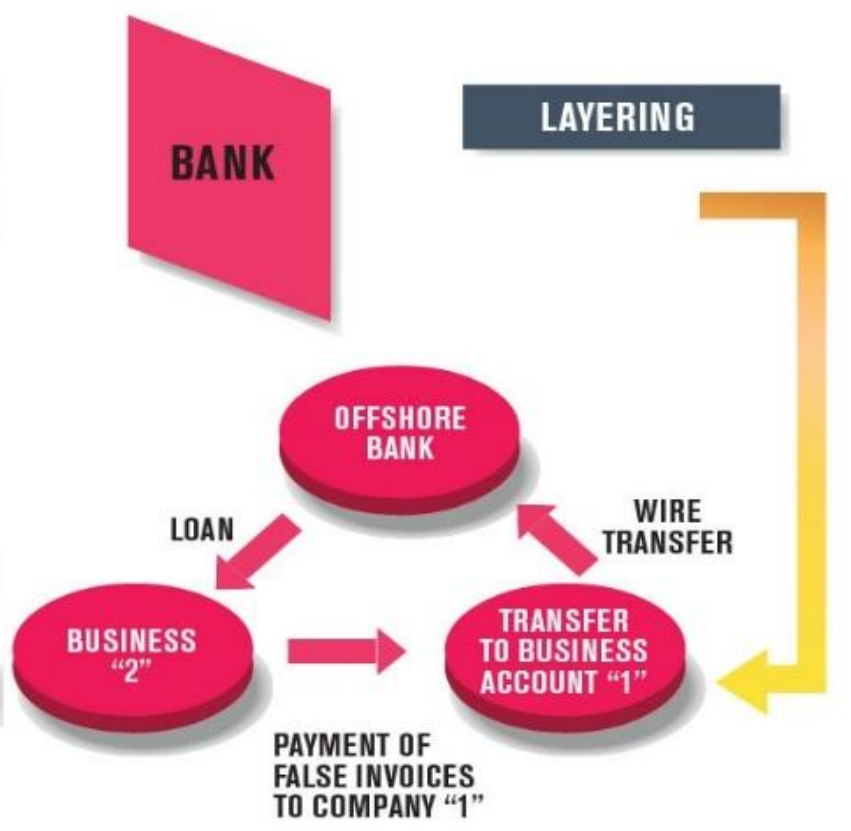

Figure 1. Basic money laundering scheme

Source: ACAMSTODAY, The Magazine for Career-minded Professionals in the Anti-Money Laundering Field
In the United Kingdom, the so-called "offshore" banking, which is characterized by extraterritoriality, developed. Offshore Banking includes branches of major international banks intending to collect deposits, managed, and disposed of by the parent institutions. A field of suspicious transactions occurs in unmanaged or insufficiently monitored locations, such as the Maldives, Marshall Islands, Cook Islands, the Dominican Republic, Luxembourg, Cyprus, Malta, Ireland, and others, in which the coefficient of monetary institutions' total funds relative to national GDP is higher. (Zirojevic, 2017, pp 16-26)

As a special type of money laundering, banking transactions performed by extremely wealthy individuals in a country should be noted. Given the reputation and material distinction these individuals possess, they also enjoy certain privileges with banks. This creates a private relationship on a bank-individual relationship, creating perfect conditions for illegal actions. Such a private relationship between the client and the bank allows certain transactions to be concealed, implemented beyond the provisions and regulations, for which the bank charges its "commission" and thus compensates for its risk of illegal work. Among the jobs that are done in this private relationship are counseling on property planning, investment, tax regulation, the opening of "shore" accounts, and involvement in complex procedures that involve the provision of financial transactions. The world's most famous is "City bank", based in the United States dealing with this type of business. It operates all over the world, has $\$ 700$ billion of well-known assets, and over $\$ 100$ billion in secret accounts of clients in private banks. 


\section{PREVENTIVE MEASURES IN COMBATING MONEY LAUNDERING}

As can be deduced from the previous exposure, money laundering is a complex and damaging action, with several different enforcement mechanisms. As it falls within the category of recent criminal offenses in the relatively recent past, new and more effective measures to prevent money laundering are still being developed. (Cudan \& Fijat, 2015, p. 144.)

In the fight against money laundering, both national legislation and international law institutions and institutions of supranational domestic legislation take part. Thus, in June 2015, the European Union adopted the Directive (EU) $2015 / 849$ - prevention of the use of the financial system for the purposes of money laundering or terrorist financing. It enhances the application of risk-based approaches through strengthening oversight, rules for determining the actual owner, politically exposed individuals, and monitoring measures and good customer knowledge. Also, on the international level, bodies have been established, whose task is international prevention of money laundering and suppression of its harmful consequences. Thus, in 1997, the Committee of the Council of Europe established the Committee of Experts on the Evaluation of Anti-Money Laundering and Financing of Terrorism (MANIVAL), whose task is to assess the compliance of anti-money laundering and terrorist financing systems in member states with international systems. For this purpose, MANIVAL collects information and evaluates anti-money laundering measures in each Member State. After that, a draft of the harmonization is being drafted, and then the final version adopted at the plenary session. The final report contains an analysis of the situation, assessment of the situation, and recommended measures to improve the fight against money laundering. This body also has certain repressive measures, which it can apply to those members who do not respect the given recommendations. Repressive measures are reflected in the obligation to send regular reports, to send a diplomatic mission to that member, and to exclude that state from the community, as the most stringent measure.
In addition to MANIVAL, the Basel Committee, which deals with the supervision of banks, was established. He works on international cooperation to improve the control of banks' operations. It consists of the USA, Japan, China, France, Germany, Great Britain, Italy, Belgium, Russia, Australia, Canada, Argentina, Brazil, India, Indonesia, Korea, Luxembourg, Mexico, the Netherlands, Saudi Arabia, Singapore, South Africa, Spain, Sweden, Switzerland, and Turkey. Within the framework of the Basel Committee, four groups operate, and these groups for the implementation of standards, the development policy group, the accounting groups, and the consulting group. In addition to these groups, there are two subgroups within the committee. (Vukotic, 2012, pp. 14-22)

In 1989, a Financial Action Task Force against Money Laundering (FATF) was established in Paris, which promotes the policy of effective fight against money laundering and terrorist financing. FATF monitors the prevention of money laundering and cooperates with international institutions dealing with this activity. Also, this body has issued Guidelines for the Assessment of Money Laundering Risk, which defines money laundering and defines principles for assessing the risk of money laundering. (International standards on combating money laundering and financing of terrorism and proliferation of weapons of mass destruction, 2012.)

It primarily focuses on business risks and risk assessment methods, and principles of risk recognition are given. Among the risks is the risk of the state, that is, the geographical risk, then the risk of the client, and the risk of the transaction. The country risk or geographic risk is associated with the location of the client and the destination of the transaction. Which location has the category of high or low-risk location, determine parameters such as the country's exposure to sanctions, embargoes, then the level and degree of state cooperation with the IMF or the World Bank, then there are indications that the state finances terrorist organizations and its activities, as well as the rate of corruption in a given country. The risk of a client is a risk on the side of the party itself in a business relationship. Based on risk, clients are selected according to whether they perform their transactions in the usual way and under normal circumstances, whether on the client's side the 
ownership structure is evident, whether clients use cash, including informal money transfer agencies, exchange offices, and casinos, humanitarian organizations that are not subject to controls, then whether they are politically-motivated clients, as well as persons carrying out transactions of higher value. (Strategy of the risk assessment of money laundering and financing of the Government of the Republic of Serbia, 2018.)

When assessing the risks of transactions, services, and products, it is based on international standards that determine certain services as highrisk services. These are international correspondent services and private banking services. Then, high-risk services include banknotes and precious metals trading, services that guarantee customers anonymity, value-added services, betting services, and casinos, services without direct contact with customers, and onetime transactions. (Pantelic, 2016, pp. 48-52)

\section{CONCLUSION}

Money laundering is a criminal offense with a high degree of social danger. In its character, it is derivative, because it follows after some other criminal offense, by which its perpetrator has obtained unlawful material gain. By money laundering, this illegally acquired money is placed in legal frameworks, thus legalizing the capital of those persons who have acquired it through the act of criminal offense. It is usually a capital that is acquired through a corrupt activity, trade-in influence, smuggling, wholesale trade, war profiteering, and in some other similar way. I am prancing money, except that money that is acquired is illegally given legality, these funds are directed to some other illegal and socially dangerous activities, such as terrorism and organized crime.

\section{WORKS CITED}

ACAMSTODAY. (2015, 08 24). Money Laundering Table. The Magazine for Career-minded Professionals in the Anti-Money Laundering Field. Retrieved from: https://www.acamstoday.org/virtual-currencies-money-laundering-cycle/money-launderingtable/

Bejatovic, M; \& Bejatovic, G. (2017). Money laundering as a negative phenomenon of economic development. Law Faculty of Probation and Justice, University Privredna akademija, Novi Sad.

Boskovic, G. (2004). Money Laundering Methods in Banking Business. Security, (46). Belgrade. 
Cudan, A; \& Fijat, A. (2015). Risks and prevention of money laundering. Printeks, Subotica.

International standards on combating money laundering and financing of terrorism and proliferation of weapons of mass destruction, Recommendations FATF. (2012). Anti-Money Laundering and Terrorist Financing Project in Serbia. MOLI, Serbia.

Pantelic, J. (2016). National Assessment of Money Laundering Risk in the Republic of Serbia. Council of Europe, Office in Belgrade.

RS Government. (2018, 05 31). National Money Laundering and Terrorist Financing Risk Assessment. Retrieved from: https://www.nbs.rs/internet/english/55/55_7/55_7_4/index.html

Vukotic, S. (2012). International problem of money laundering. University Singidunum, Belgrade.

Zirojevic, A. (2017). The Specific Features of Money Laundering in the Banking Sector. Law: Theory and Practice, Journal of the Association of Lawyers of Vojvodina, (7-9).

Received for publication: $\quad 23.02 .2020$

Revision received: $\quad 17.06 .2020$

Accepted for publication: $\quad 01.07 .2020$

\section{How to cite this article?}

Style - APA Sixth Edition:

Miljkovic, L., Trnavac, D., \& Antonovic, R. (2020, July 15). Prevention of money laundering in the banking sector. (Z. Cekerevac, Ed.) MEST Journal, 8(2), 137-142. doi:10.12709/mest.08.08.02.15

Style - Chicago Sixteenth Edition:

Miljkovic, Ljubomir, Dragana Trnavac, and Ratomir Antonovic. 2020. "Prevention of money laundering in the banking sector." Edited by Zoran Cekerevac. MEST Journal (MESTE) 8 (2): 137-142. doi:10.12709/mest.08.08.02.15.

Style - GOST Name Sort:

Miljkovic Ljubomir, Trnavac Dragana and Antonovic Ratomir Prevention of money laundering in the banking sector [Journal] // MEST Journal / ed. Cekerevac Zoran. - Belgrade - Toronto : MESTE, July 15, 2020. - 2 : Vol. 8. - pp. 137-142.

Style - Harvard Anglia:

Miljkovic, L., Trnavac, D. \& Antonovic, R., 2020. Prevention of money laundering in the banking sector. MEST Journal, 15 July, 8(2), pp. 137-142.

Style - ISO 690 Numerical Reference:

Prevention of money laundering in the banking sector. Miljkovic, Ljubomir, Trnavac, Dragana and Antonovic, Ratomir. [ed.] Zoran Cekerevac. 2, Belgrade - Toronto : MESTE, July 15, 2020, MEST Journal, Vol. 8, pp. 137-142. 